\title{
The WebQuest: Its impact on students' critical thinking, performance, and perceptions in physics
}

\author{
Auditor, Edwin \\ Philippine Normal University, Philippines (e.auditor0729@gmail.com) \\ Roleda, Lydia \\ De La Salle University, Philippines (lydia.roleda@dlsu.edu.ph)
}

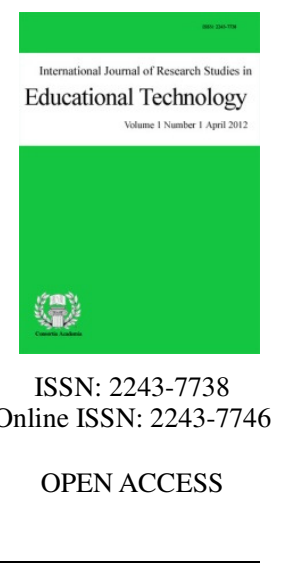

\begin{abstract}
This paper investigated the impact of WebQuest on students' critical thinking, content-knowledge acquisition, task performance and perceptions in basic Physics. This study also determined which aspect of critical thinking was best or least demonstrated by the students, and examined the correlation between students 'critical thinking and task performance and the relationship between students' content-knowledge acquisition and perceptions. The study employed both descriptive and inferential data analysis procedures. More broadly, this study utilized a case study format. As such, through classroom observations, structured and unstructured interviews, the researcher gained a deeper understanding of the students' views and experiences. The key findings of this study showed that participants had significant gains in both critical thinking and content-knowledge acquisition. As far as students' perceptions were concerned, the analysis also showed that students responded positively on the use of WebQuest model in terms of collaboration, creativity, motivation, and knowledge enhancement but were not in time management. A low to moderate, correlation was found between critical thinking and task performance. In contrast, there was negligible correlation between students' academic performance and perceptions. Thus, this study demonstrated that students viewed WebQuest favorably irrespective of their ability to learn and it suggests that WebQuest model can be a useful tool for student learning.
\end{abstract}

Keywords: WebQuest; critical thinking; deduction; model of teaching; authentic problem-solving 


\section{The WebQuest: Its impact on students' critical thinking, performance, and perceptions in physics}

\section{Introduction}

As the personal computer came into common use worldwide, the Internet has become an important tool for most of the students and professionals. With this emerging technology, many teachers have adopted the idea of using WebQuests to effectively use the internet in the classroom while engaging their students in the kinds of thinking necessary to capitalise on recent technological advancement (Chou, 2007). What is a WebQuest? According to Dodge (2007), "a WebQuest is an inquiry-oriented lesson format in which most or all the information that learners work with comes from the web". With the ongoing acceptance of WebQuests by both teachers and students, it has spread to other countries like Brazil, Spain, China, Australia and Holland (Dodge, 2007). This teaching model has now been utilized across various disciplines in education (Chuo, 2004). Like many educational pursuits however, it is essential to continually evaluate the impact of this teaching model on the teaching and learning process.

According to Watson (1999) and Rodriguez (2003), since the inception of Webquest in 1995, it has become a prime means of engaging students in constructive web-based learning activities and eventually reforming traditional practice. Dudeney (2003) and March (2004) recognized the WebQuests potentials as a teaching model. They accentuated some benefits such as providing a relatively easy way to incorporate the Internet into a language curriculum, encouraging critical thinking, leading to productive interaction through collaborative tasks, and promoting learner motivation through interdisciplinary studies as well as "real-life" tasks. Ikpeze \& Boyd (2007) emphasized that the use of WebQuest promotes collaboration, thoughtful connections and critical reading which can augment motivation and other computer related skills.

Cheng, Tzung, and Wei, (2011) investigated the impact of WebQuest in outdoor instruction. The study reveals that WebQuest influences students' learning performance positively. Specifically, when students engaged in a WebQuest activity, students acquire more knowledge and experiences. Students also accomplished different learning tasks and expressed their own opinions and perspectives, which could promote their critical thinking skills. Tsai (2006) investigated the effect of the WebQuest when it is infused to English as a foreign language (EFL) instruction. The study found a correlation between motivation and perceived learning vocabulary. Specifically, the results showed that the integration of the WebQuest produced a significant difference in student vocabulary acquisition, reading skills, and reading comprehension in an EFL course.

According to Mohn (2003), Brown and Zahner (2006), Goddy (2007), and Ikpeze and Boyd (2007); WebQuests can promote student achievement or thoughtful literacy when tasks are carefully chosen, structured, and carried out. Gowen (2010) sought to find the answer to how well students learn and are motivated by the WebQuest. The key findings of his study revealed that WebQuest was effective and useful to improve student's achievement specifically, in gifted and average learners. However, no correlation was found between multiple intelligences preference and achievement or motivation.

While WebQuests are often mentioned as an exemplary strategy for the effective integration of technology in teaching and learning, Abbit and Ophus (2008), argued that "one overarching issue with what is known about the WebQuest strategy is the scarcity of research on the effects of this strategy on teaching and learning" (p.42). Thus, there have only been a limited number of studies that have investigated on the effects of WebQuest on learning and achievement. Furthermore, it is not known to what extent the use of WebQuest model in teaching Physics at the high school level impacts students' critical thinking, and academic and task performances.

Although learning Physics is an indispensable and valuable goal, attention should also be focused on teaching model that could enhance students' critical thinking. Consequently, this study aimed to provide the initial work that would describe the impact of WebQuest on students' critical thinking, performance, and their 
perceptions on WebQuest model in physics class.

\section{Methods}

\subsection{Research Design}

In this study, Mixed Method Design [i.e. quantitative and qualitative methods] was used in complementary fashion. Qualitative data were used to explain students' thoughts on the WebQuest effectiveness and explained findings from the analyses of quantitative data.

\subsection{Subjects}

The study took place in an international school in Muntinlupa City, Philippines. Twenty [20] students participated in the study which lasted for almost five [5] months [September 2010 through February 2011]. All participants were physics students, who were taking the course as part of their basic education program for the school year 2010 to 2011. The students were composed of seven [7] boys and thirteen [13] girls, mixed nationalities with ages ranging from fifteen [15] to seventeen [17] years. They were selected on the basis of class membership. Prior to the study, they were grouped into five of four members according to their first quarter grades in Physics. Only scores of students who had completed both the pretest and posttest critical thinking assessments and physics content exam were included in the data analysis.

\subsection{Instruments}

The data were collected through the following instruments: the Cornell Critical Thinking Test -Level X [CCTT-X], California Physics Standard Test [CPST], a survey questionnaire, the students' performance-based evaluation and the teacher field notes. The tests were administered in different modes: CCTT-X was delivered in the computer-based mode whereas CPST and student satisfaction questionnaire were administered in the paper-and-pencil mode.

The CCTT-X was administered as the pretest and posttest. It was used to determine the critical thinking skills of the students. Although the CCTT-X contains 76 items, some items [1, 2, 26, 51 and 66] are used as sample items, hence, it only contains 71 -item multiple-choice test intended to be taken in a 50 minute period. Each item has three choices and one keyed answer. Subtests cover identification of assumptions [10 items], induction [23 items], deduction [14 items], observation statements, judging credibility [24 items], meaning and dispositions [not directly tested]-all aspects of critical thinking.

To determine the proficiency level of the participants in specified Physics skills or concepts, the researcher administered the California Physics Standard Test [Released Test Questions]. The released test questions were taken from the Physics Standard Test. Initially, the test questionnaire consisted of eighty-nine [89] questions which represent various topics in Physics. However, to ensure its appropriateness for measuring the desired skills and concepts that have been covered within the research period, the teacher-researcher chose forty-two [42] questions from the test, which included motion, forces, conservation of energy and momentum. These items were in multiple-choice format taken within a 60- minute period. Each item has four choices and one keyed answer.

To determine the performance scores of the students and to evaluate the product-type objectives of each WebQuest activity, the researcher applied the Project Execution Test [PET]. This outcome-based assessment technique evaluated performance of the students upon carrying out an activity or project in a certain period of time. Some of these products included prepared PowerPoint presentation, creative presentation and threedimensional projects. The researcher assessed each of participants works [generated product or fulfilled task within deadline] that were completed in targeted objectives using a specifically- designed rubric. The assessment results were then compiled for analysis. 
Throughout the duration, the teacher-researcher kept a logbook of daily activities or events and his perceptions of how the students were utilizing the WebQuest pieces of information. The journal [log] allowed the researcher to make a written account of the WebQuest activities and student's behavior in class. The notes were taken based on the actual or direct observations of the researcher while students were working on the assigned task. Moreover, it recorded the description of the activities such as date, time, objectives, work done, things that worked well, things that did not work very well and other important details were all written.

Finally, to provide a picture of the students' perceptions regarding the use of the WebQuest model, the researcher had utilized personal interviews and a student satisfaction survey. The participants were given a student satisfaction questionnaire, 6 items in the Likert rating scale format and 1 item, open-ended.

\subsection{Procedures}

The study was carried out according to the following stages:

\section{Onset}

This stage set forth the acquisition of the Cornell Critical Thinking Test-Level X [CCTT-X] and the California Physics Standard Test [CPST], and their administration. The researcher met with the concerned individuals such as the school principal and vice-principal to explain the data collection procedures and to make arrangements for computer lab usage for the pretesting and post testing. Later, the two instruments, the CCTT-X and CPST were administered as pretest, respectively.

\section{In progress}

Prior to the implementation of the WebQuest model, a brief overview of the said model was explained to the participants. They were told that they would be completing a series of WebQuests about various physics concepts and the teacher wanted them to have a chance to experience what it would be like if they had to perform like a scientist, engineer, journalist etc. for instance [i.e. playing various roles in class]. Before they went to the computer lab they were instructed to fill out a KWL chart on which they were asked what they knew, and what they wanted to know. Then, they were split up into pairs or small groups of four members. If the activity was a short-term WebQuest, they were required to complete a worksheet with questions from the WebQuest. On the other hand, for longer term WebQuest, they had to learn the subject matter in a profound manner and subsequently applied the concepts in creating a tangible product. After completion of each WebQuest, they were asked about what they learned from the WebQuest and what they like best or what they did not like. They were also informed that they would be evaluated using an alternative assessment method instead of traditional quizzes. Then, the rubric for this assessment was explained to them. The participants underwent different schemes of WebQuest over four (4) months.

\section{Final}

To complete the study, students were given the CPST and student satisfaction survey. This was followed by a re-administration of the CCTT-X. The posttest was given almost five months after the pretest. This interim guaranteed against the possibilities of test-wisdom. Toward the end of treatment, the researcher generally explained the rationale for taking the tests and students were told that the data from the instruments would help the faculty evaluate instruction and that their scores would be part of their final grade. This was to ensure that the participants would take the test seriously.

\section{Data Analyses}

The approach of this study adopted Non-Experimental Design [Qualitative] and Pre-Experimental Design [Quantitative], particularly the One Group Pre Test -Post Test Design. As for quantitative measurement, the study employed both descriptive and inferential data analysis procedures. Descriptive statistics like means and 
standard deviations were calculated, particularly of each subscale score and the total score of the participants, to provide information concerning the sample and distribution of data. Since the same sample has been measured on two occasions [pretest-posttest] on the same dependent variables [critical thinking and knowledge acquisition], gain scores and normalized gain scores $\mathrm{G}$ were used in assessing students' performance in pre- and posttests. Likewise, paired t-tests were conducted to evaluate whether there is a significant difference between the means of the two occasions. To describe the relationship between students' critical thinking and task performance, Pearson's Product-Moment correlation coefficient was determined. Finally, to describe students' task performances, WebQuest outputs such as roller coaster model, PowerPoint presentation, oral and written report were evaluated by using rubrics. More broadly, this study utilized a case study format. As such, through classroom observations, structured and unstructured interviews, and surveys, the researcher gained a deeper understanding of the students' views and experiences.

\section{Results and discussion}

Research Question 1: Is there a significant gain in critical thinking following a period of instruction using WebQuest model?

The Cornell Critical Thinking Test-Level X [CCTT-X] was used to measure the critical thinking skills of participants and was administered before and after the treatment. The results of the CCTT-X pretest and posttest are displayed in Figure 1 [a]. To achieve a better observation on these data, the individual students' CCTT-X scores were analyzed using gain scores and normalized gains $\mathrm{G}$ [see Figures 1b, and 1c]. Figure 1a clearly shows that there was in general, an increase in the students' group scores. However, it is very apparent that the WebQuest model has affected the students differently, specifically [see Figure 1 (b)]; a negative gain score was observed for students 1, 8 and 11 [Mean Gain = -14.00\%]; leveling-off of gain score for student 19 [Mean Gain $=0 \%$ ]; slight increase for students 13, 17, 3, 20, 15, 7and 4 [Mean Gain = 7.57\%]; and remarkable gain scores for students 2, 5, 6, 10, 12 and 16 [Mean Gain $=46.22 \%$ ].

On the other hand, when analyzing the value of each student's normalized gain G [see Figure 1 (c)], it is important to note that students [1, $8 \& 11]$ have obtained negative $G$ [ $G=-23.67 \%$; no change for student 19 [G $=0.00 \%]$; eight of the twenty students $[14,9,13,20,17,3,4, \& 7]$ showed slight increase $[\mathrm{G}=10.75 \%]$ and noteworthy achievement for students $10,16,12,6,2,5$, and 18 [G $=37.00 \%]$. The data indicated, however, that the effect of the WebQuest was the same for the students. Students 14 and 9 were the exception.

Furthermore, information from a question-by-question basis, which is useful for further analysis on how students responded before and after the test, could not be presented in this study due to the fact that CCTT-X was administered through a proctored web-based setting; that is students were only given the relative score [i.e. total score or subtest score]. However, when considering the group's mean [see Table 1(a)], it is noteworthy that there is a considerable WebQuest effect. The mean score of 35.00 [SD=9.77] for the pretest increased to 40.55 for the posttest with a standard deviation of 9.46 .

To establish if there is a significant difference in the critical thinking prior and after WebQuest instruction, a paired-sample t-test was used. As indicated in $1 \mathrm{~b}$, there is a significant difference in the scores for pretest and posttest $[M=-5.55, S D=8.35]$ conditions; $t$ [19] $=-2.97$, $\mathrm{p}$ was less than 0.05 . The $95 \%$ confidence interval for the group mean difference ranges from -9.458 to -1.642 . It does not include zero so the mean gain is different from zero. That is, there was significant improvement for students' critical thinking. This result implies that exposure to the WebQuest model as a teaching learning experience has an effect on the students' critical thinking skills. One possible reason might be that students were given an authentic task and challenged them to fully engage themselves. According to Christie (2007) when students are placed in a "structured environment" they need to be proficient in several areas [i.e. using internet, word processor and the like] before completing their task. It was also necessary for students to have some background in the aimed concepts, specifically, on the physics of roller coasters. This allowed them to practice higher-order thinking skills such as analysis, synthesis 
and evaluation in order to make inferences, and interpret extensive information from the Internet and print resources. These thinking skills help students solve the presented problems. Nonetheless, the results of this study corroborated the earlier observations of Vidoni and Maddux (2002), Crawford and Brown (2002), Vanguri, et. al. (2004), Puthikanon (2009), Li (2009) and Cheng, Tzung, \& Wei, (2011) that WebQuest is an effective tool for encouraging critical thinking.

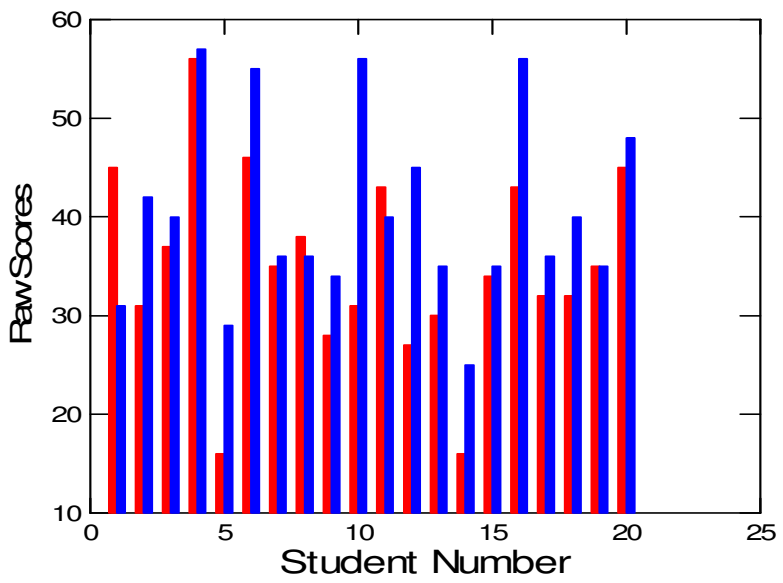

(a)

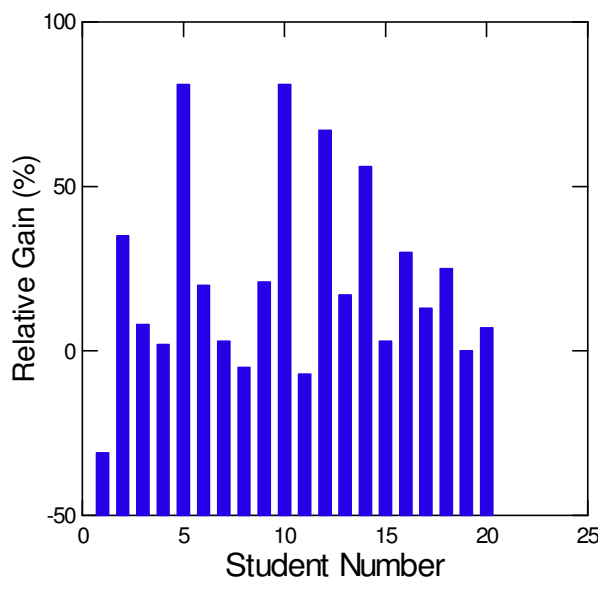

(b)

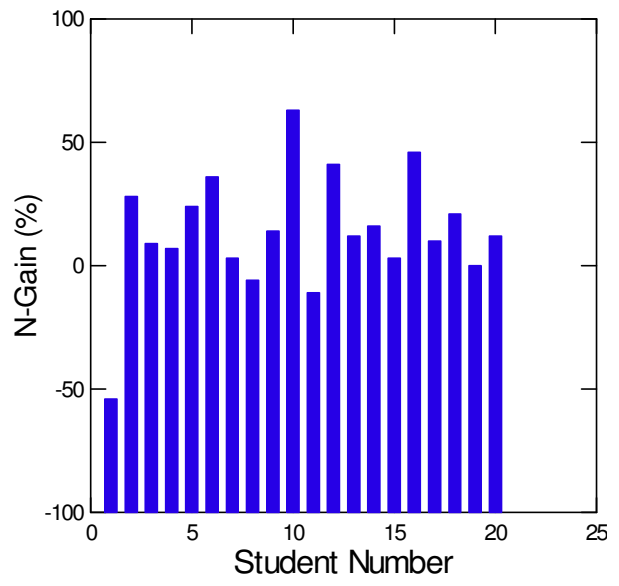

(c)

Figure1.

(a) Plot of individual students' pre-posttest CCTT-X raw scores [rights- only scoring].

(b) Plot of individual students' CCTT-X relative gains.

(c) Plot of individual students' normalized CCTT-X gains G.

\section{Table 1}

(a) Mean and Standard Deviation of CCTT-X Pre-Post Test Scores [Rights- Only Scoring]

\begin{tabular}{|c|c|c|c|c|c|c|c|}
\hline \multirow[t]{3}{*}{ ССТT-X } & Mean & $95.00 \%$ & Confidence & \multirow{3}{*}{$\begin{array}{l}\text { Standard } \\
\text { Deviation of } \\
\text { Difference }\end{array}$} & \multirow[t]{3}{*}{$\mathrm{t}$} & \multirow[t]{3}{*}{ df } & \multirow[t]{3}{*}{ p-Value } \\
\hline & \multirow{2}{*}{ Difference } & Interval & & & & & \\
\hline & & $\begin{array}{l}\text { Lower } \\
\text { Limit }\end{array}$ & Upper Limit & & & & \\
\hline Pre-Posttes & -5.550 & -9.458 & -1.642 & 8.351 & -2.972 & 19.000 & 0.008 \\
\hline
\end{tabular}


The WebQuest: Its impact on students' critical thinking, performance, and perceptions in physics

(b) Significance Level p of CCTT-X Pre-Post Test Scores [Rights - Only Scoring]

\begin{tabular}{lllll}
\hline CCTT-X & Mean & N & Std. Deviation & Std. Error Mean \\
\hline Pretest & 35.00 & 20 & 9.77 & 2.18 \\
Posttest & 40.55 & 20 & 9.46 & 2.11 \\
\hline
\end{tabular}

Research Question 2: Which of the components of critical thinking skills was best demonstrated by the students? Which was the least demonstrated by the students?

Both sets of scores [from pretest and posttest] were analyzed. As indicated in Figure 2, it is interesting to note that the group excelled in deduction. Specifically, the mean pretest score was 44.15 [SD $=17.15]$, while the mean posttest score was 61.20 [SD $=11.78]$. This represents a significant change [p $<0.001]$ [see Table 1]. The performance in deduction considered the participants' abilities to ascertain whether a proposed conclusion supports the given statement, contradicts or neither - essential cognitive component and fundamental in any learning process (Jarus, 2001). But, the result for Assumption Identification was also noteworthy because of the lowest average percentage obtained. The mean pretest score was 35.00 [SD $=16.38$ ] while the mean posttest score was 43.50 [ $\mathrm{SD}=15.98]$. This difference was not statistically significant $[\mathrm{p}=0.312]$. This implies that students' poor ability in keying out the statement that sufficed for the reasoning did not change significantly.

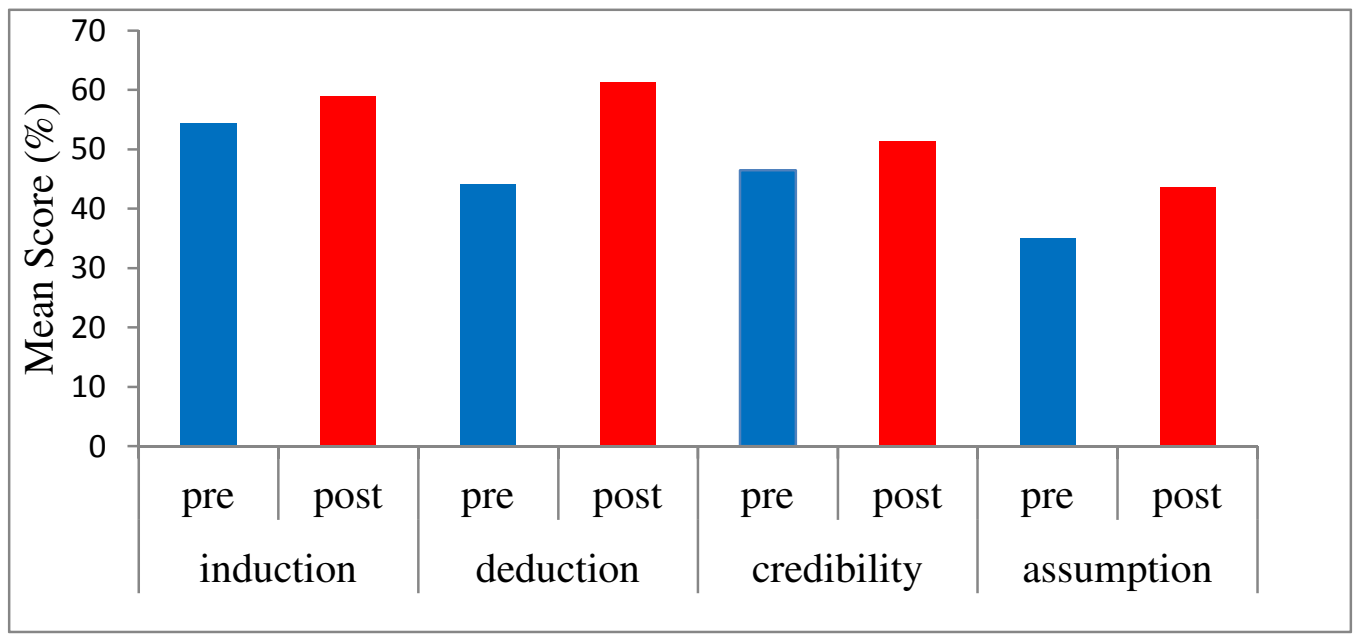

Figure 2. Plot of individual students' pre-posttest CCTT-X percent scores by aspects.

Table 2

Mean and Standard Deviation of CCTT-X [Per Aspect] Pre-Post Test Scores

\begin{tabular}{lllllll}
\hline Aspects & Pretest & \multicolumn{3}{c}{$\begin{array}{l}\text { Posttest } \\
\text { M (\%) SD }\end{array}$} & \multicolumn{3}{c}{ SD } & t value \\
\hline Induction & 54.40 & 12.94 & 59.00 & 14.90 & -1.272 & 0.219 \\
$\begin{array}{l}\text { Deduction } \\
\text { Observation }\end{array}$ & 44.15 & 17.15 & 61.20 & 11.78 & $-3.822 *$ & 0.001 \\
\&Credibility & 46.45 & 15.34 & 51.30 & 18.92 & -1.059 & 0.303 \\
Assumptions & 35.00 & 16.38 & 43.50 & 15.98 & -1.722 & 0.101 \\
\hline
\end{tabular}

Note. ${ }^{\mathrm{p}}<0.001$ and higher

Throughout this computation, a moderate improvement was also observed in the participants' induction and credibility thinking abilities. As in the case of induction, the mean pretest score was 54.40 [SD= 12.94], relatively high among all aspects, while the mean posttest score was 59.00 [SD=14.90]. However, this difference was not statistically significant $(\mathrm{p}=0.219)$. The WebQuest did not alter the participants' abilities in sorting out patterns and irregularities of suggested facts - essential in formulating theories and discovering 
relationship (Herr, 2007) significantly. On the other hand, mean pre-observation and credibility score was 46.75 [SD $=15.34$ ], while the mean post-observation and credibility score was 51.30 [ $\mathrm{SD}=18.92]$. This difference was not statistically significant $(\mathrm{p}=0.101)$. Though not a significant change, it is still interesting to note that the students already possess good observation and credibility skills. It seems that the WebQuest intervention does not change the students' ability to judge whether, and to what extent, to accept someone else's assertion as what Ennis et al. (2005) called "Observation and Credibility of Sources".

Among the aspects that were tested, only deduction showed changes that were statistically significant [p $<.001]$. This implies that the treatment enhanced the ability of the participants in identifying plausible information or reasoning that supports the hypothesis. It also enhanced the ability to determine the proposed conclusion which emphasizes the importance of being able to reason neutrally as what Wilkins (1928) called "suggestive content" (as cited in Ennis, R., Millman, J.\& Tomko, T., 2005). It stands to reason that this result was anticipated since deductive and inductive aspects were most frequently utilized when students were engaged in problem solving and decision making (Dewey, 1933/1998). Deduction was best exemplified by asking students to design a virtual roller coaster track prior to building an actual model. The task was very deductive in nature in view of the fact that students were given a chance to apply laws of motion, principle of conservation of energy and other related concepts such as speed, velocity, acceleration, etc. and calculate what happens to the roller coaster when the height of hills, length of track, mass of the coaster, speed of the coaster and other variables are changed. Moreover, deductive reasoning was apparent the way students make generalizations, draw inferences and verify conclusions [i.e. theories, laws or principles] by applying to a specific situation in which in this case building a roller coaster model. But then, the lowest score aspect suggested that assumptions identification was perhaps the most challenging part of critical thinking to be enhanced.

Overall, the findings of this research suggest that when students were exposed to WebQuest model, their deductive reasoning was enhanced. On the contrary, analysis shows that students demonstrated less in assumptions identification. This implies that, though the WebQuest model may significantly increase the students' overall critical thinking score, some of the critical thinking aspects were not. While aspects of critical thinking were categorized, the use of individual aspect score per se to represent performance on each of the four aspects was not encouraged by the test developers since there were substantial overlaps and interdependence among them in the actual process of critical thinking (Ennis, R., Millman, J.\& Tomko, T., 2005, p.3). This was argued so because critical thinking is a complex construct (Lombard \& Grosser, 2004).

Research Question 3: Is there a significant gain in content-knowledge acquisition following a period of instruction using WebQuest model?

Content -knowledge acquisition was determined by the score on the California Physics Standard Test [CPST]. It was administered before and after implementing the WebQuest model. The test comprised of 42 selected response items and the score was determined by summing the number of correct items [maximum possible score is 42]. Pretest and posttest content knowledge scores were summarized in Table 3a. Pretest mean score for the group was 16.00 with standard deviation of 5.06. The data showed that after the WebQuest, the mean increased to 35.65 with a standard deviation of 4.50. A paired t-test indicated that there was a significant difference $[\mathrm{M}=-19.60, \mathrm{SD}=3.82]$ conditions; $\mathrm{t}[19]=-21.03$, $\mathrm{p}$ was less than 0.0001[Table 3b]. Inspection of the 95\% confidence intervals around mean difference indicated that the mean difference ranges from -21.436 to -17.864. The interval does not contain zero so the mean gain is different from zero. That is, there was significant improvement for students' content-knowledge acquisition. Consequently, this statistically significant difference or significant increase is an indication that the students benefited academically [i.e. content-knowledge acquisition] from the WebQuest intervention. This is in agreement with the earlier works of Mohn (2003), Brown \& Zahner (2006), Tsai (2006), Ikpeze and Boyd (2007), Gaddy (2007), Gowen (2010), and Cheng, Tzung, and Wei, (2011) that WebQuest promotes participants' learning and achievement. 


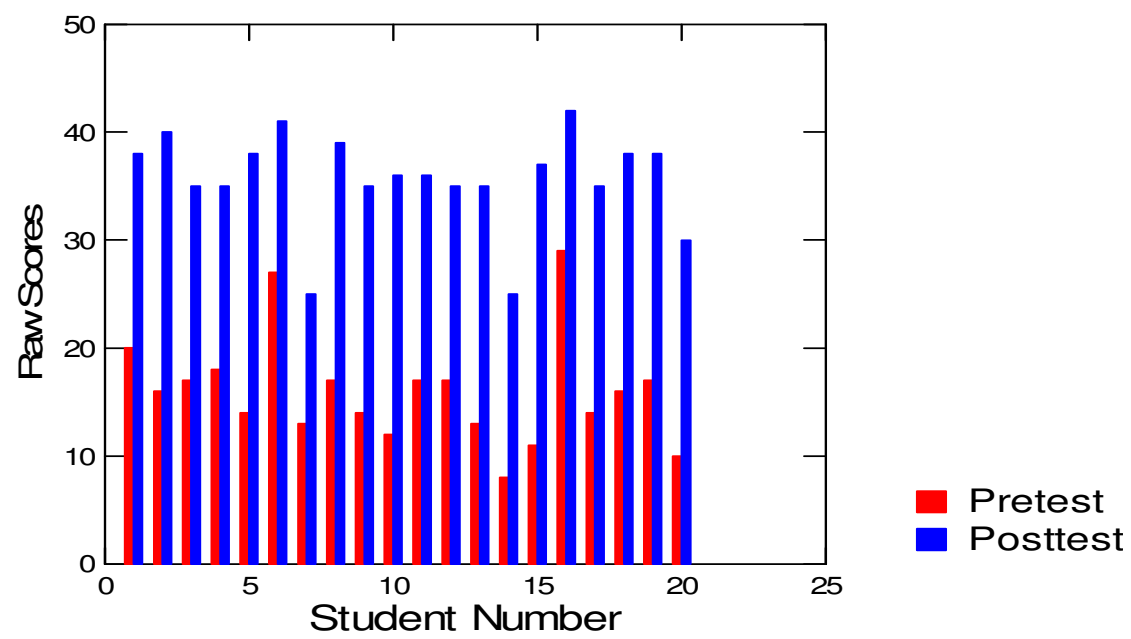

Figure 3. Plot of individual students' pre-posttest CPST raw scores [rights-only scoring].

Table 3

(a) Mean and Standard Deviation of CPST Pre-Post Test Raw Scores

\begin{tabular}{lllll}
\hline $\mathrm{c}$ & Mean & $\mathrm{N}$ & Std. Deviation & Std. Error Mean \\
\hline Pretest & 16.00 & 20 & 5.06 & 1.13 \\
Posttest & 35.65 & 20 & 4.50 & 1.01 \\
\hline
\end{tabular}

(b) Significance Level p of CPST Pre-Post Test Scores

\begin{tabular}{|c|c|c|c|c|c|c|c|}
\hline \multirow[t]{2}{*}{ CPST } & \multirow{2}{*}{$\begin{array}{l}\text { Mean } \\
\text { Difference }\end{array}$} & \multicolumn{2}{|c|}{$95.00 \%$ Confidence Interval } & \multirow{2}{*}{$\begin{array}{l}\text { Standard } \\
\text { Deviation of } \\
\text { Difference }\end{array}$} & \multirow[t]{2}{*}{$\mathrm{t}$} & \multirow[t]{2}{*}{ Df } & \multirow[t]{2}{*}{ p-Value } \\
\hline & & Lower Limit & Upper Limit & & & & \\
\hline
\end{tabular}

\begin{tabular}{llllllll}
\hline Pre-Post & -19.650 & -21.436 & -17.864 & 3.815 & -23.034 & 19.000 & 0.001 \\
\hline
\end{tabular}

Research Question 4: Is there a relationship between the students' critical thinking skills and their task performance after engaging them in learning process using WebQuest model?

The Critical thinking was determined by the score on the posttest of the CCTT-X while task performance was determined by the total score on the performance-based evaluation. Figure 4 shows a good visual picture of the relationship between critical thinking and task performance [two continuous variables against each other]. The distributions of each variable appear at the borders of the plot. The upward trend clearly shows that there was a positive association between critical thinking and task performance.

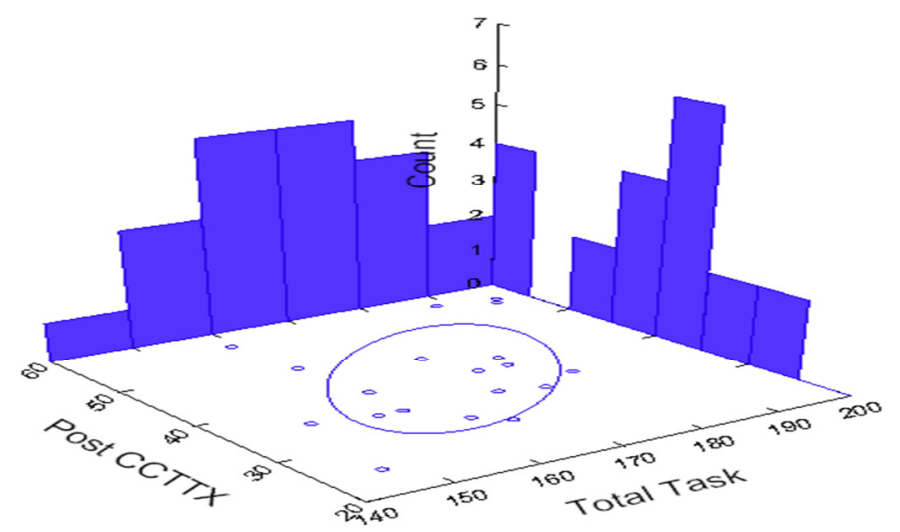

Figure 4. Plots of Critical thinking and task performance. 
Auditor, E., \& Roleda, L.

To achieve a better observation on the relationship, the Pearson product-moment correlation coefficient was computed. There was a low to moderate correlation between the two variables, $\mathrm{r}(18)=0.529, \mathrm{p}<.02$ [see Table 4]. Overall, there was statistically significant correlation between students' critical thinking and task performance. That is, the students' performance of the learning task had strong positive relationship with their critical thinking skills. This indicated that students' high scores on the performance task are directly related to their high scores on measures of critical thinking and vice versa.

Table 4

Critical Thinking and Task Performance with Pearson Product-Moment Correlations

\begin{tabular}{lll}
\hline & Post-Critical Thinking & Task \\
& & Performance (Total) \\
\hline Post-Critical Thinking & 1.000 & \\
Task Performance (Total) & $0.529^{*}$ & 1.000 \\
\hline
\end{tabular}

$* p<.02 ; d f=2$

A summary of the results of correlations between the critical thinking aspects and selected task performances are presented in Table 5. The computed coefficients for most aspects and task performances were within the small range [i.e. <.20] suggesting that the relationships between these critical thinking aspects and task performances were negligible. Further analysis shows that deduction, and observation and credibility, however, were found to be weakly to moderately and positively correlate with some task performances [i.e. PowerPoint and roller coaster]. However, it is noteworthy that there was a statistically significant positive correlation between induction and roller coaster task performance, $\mathrm{r}(18)=+.402, \mathrm{p}<.10$; between deduction and roller coaster task performance, $\mathrm{r}(18)=+.662, \mathrm{p} .01$, and between observation and credibility and roller coaster performance, $\mathrm{r}(18)=+.388, \mathrm{p}<.10$. Furthermore, the positive correlation between identifying assumptions and roller coaster task performance was also statistically significant, $\mathrm{r}(18)=+.594, \mathrm{p}<.01$. The data indicated, however, that the effect of students' critical thinking on their task performance may vary with the type of task they were asked to carry out. Such impact can be explained in terms of describing the key performance indicators-rubric used.

Table 5

Correlation Matrix for Selected Variables

\begin{tabular}{lllll}
\hline Task Performance & Induction & Deduction & $\begin{array}{l}\text { Observation/ } \\
\text { Credibility }\end{array}$ & $\begin{array}{l}\text { Identifying } \\
\text { Assumptions }\end{array}$ \\
\hline PowerPoint & 0.140 & 0.223 & 0.336 & 0.059 \\
Oral Presentation & -0.023 & -0.034 & 0.133 & -0.188 \\
Roller Coaster & $0.402 *$ & $0.662 * * *$ & $0.388^{*}$ & $0.594 * *$ \\
Skills (e.g. helping & -0.108 & -0.057 & 0.016 & -0.251 \\
listening etc.) & & & &
\end{tabular}

$* p<.10 ; * * \varepsilon \leq .05 ; * * * \varepsilon \varsigma .01 ; d f=2$

As pointed out in the preceding section, WebQuests allow students to be involved in a wide range of activities [i.e. inclusion of authentic tasks] that make good use of Internet-based resources. And, when a WebQuest requires students to create a palpable output about a certain topic or learning goals, the teacher set the expectations for the authentic task to be completed or output to be made along with the necessary constraints. That is to say, it was the key performance indicators-rubric that formed the basics of all assessments used throughout the WebQuest task.

The first task for each group was to make a PowerPoint presentation, involving Newton's Three Laws of Motion. The presentation emphasized the explanation of each law along with the necessary diagrams or 
The WebQuest: Its impact on students' critical thinking, performance, and perceptions in physics

animations, and application showing the way the laws of motion impact one's daily life. Prior to this task, students researched about the given topic and then created a slide presentation about it. However, this study revealed that there was a negligible correlation between creating a PowerPoint presentation and aspect of critical thinking performance. This could be attributed to the nature of this task [difficulty level of the task]. Although, students were confronted with various questions about Newton's laws and decided to look for information via internet, it was noticeable that students were not necessarily creating using their understanding of the said topic; instead, they were creating using their understanding of PowerPoint and perhaps some ideas about the given topic. Consequently, students could learn about Newton's Three Laws of Motion and be able to create a good presentation about it but these performances have little relationship with the students' critical thinking. One possible reason for this was explained by March (2003/2004). He pointed out that students must develop a substantively new concept [make sense of the topic] and product, not merely provide a new compilation of information [simply copying and pasting] so as to require them to use their critical thinking skills.

The second task for each group was oral reporting, concerning conservation of energy and momentum. The scenario was centered on a traffic accident investigation. After the task [i.e. acting as auto expert, collision expert, and investigator] was accomplished, each team was assigned again to report back to class on the story in the style of television news reporting. The aim was to provide information across the public sector with a detailed accident report that includes mass, velocity, and momentum of both vehicles both prior to and after the collision. However, the data in Table 5 reveals that there is no significant relationship between oral presentations and aspects of critical thinking. One possible reason for this could be traced to the criteria used to judge whether the desired level of performance has been achieved. In this task, the team's score would actually be a reflection of the team's oral presentation skills [i.e. effective use of visual aids, presentation organization, group presentation, presentation mechanics and response to questions]. As such, the score would be an inaccurate measure of the student's critical thinking. Nonetheless, the researcher's observation needs further research.

The third task was to make a roller coaster model. As discussed in the preceding section, this WebQuest provided students with the opportunity to take on the role of roller coaster designers. Using information collected from the Internet and materials that they have provided, they were able to design, build, and test simple models of roller coasters. In the testing process, one of the challenges was to identify the problems with their models and be able to solve by applying various Physics concepts in the design of roller coasters. Furthermore, the data in Table 5 reveals that there was a statistically significant relationship between roller coaster task performance and aspects of critical thinking. One possible reason for this could be attributed to appropriate exercises [e.g. problem solving and decision making] that sharpened the critical thinking skills of the students. On this, Dewey (1933/1998 points out that deductive and inductive reasoning [aspects of critical thinking] are mostly utilized when students are engaged in problem solving and decision making. As Scardamalia and Bereiter (1999) argued that,

Trying to make sense of information about a topic of interest almost always ensures that [students are engaged in solving problems]. (p. 278)

This implies that it is essential to choose a task performance that requires students to solve problems not just the ability to regurgitate facts. Furthermore, Wiggins (1990) points out that

Authentic tasks involve "ill-structured" challenges and roles that help students rehearse for the complex ambiguities of the "game" of adult and professional life. (p. 8)

As discussed in the previous section, although CCTT-X measures four aspects of general critical thinking [i e. Induction, Deduction, Observation \& Credibility, Identifying Assumptions] the test developers argued that the application of any particular skills may overlap with the other tested skills. Nonetheless, the test can still be effective in determining the extent of students' critical thinking skills.

Research Question 5: What are students' perceptions regarding WebQuest model in learning Physics? 
In this study, the teacher-researcher evaluated student perceptions of WebQuest by using his personal observation, interview and a survey that elicited the students' thoughts on the WebQuest model. At the course conclusion, students were asked to assess their impressions on WebQuest, perceptions of WebQuest effectiveness in acquiring content-knowledge, promoting creativity, managing time, and their perceptions of successful interpersonal relationships within groups. The participants were administered a student satisfaction questionnaire in the Likert scale format, 1-to-5 rating scale [being 5 the highest].

The survey's first question was, "How well do you think you collaborated with your partner/group mates for this WebQuest?"

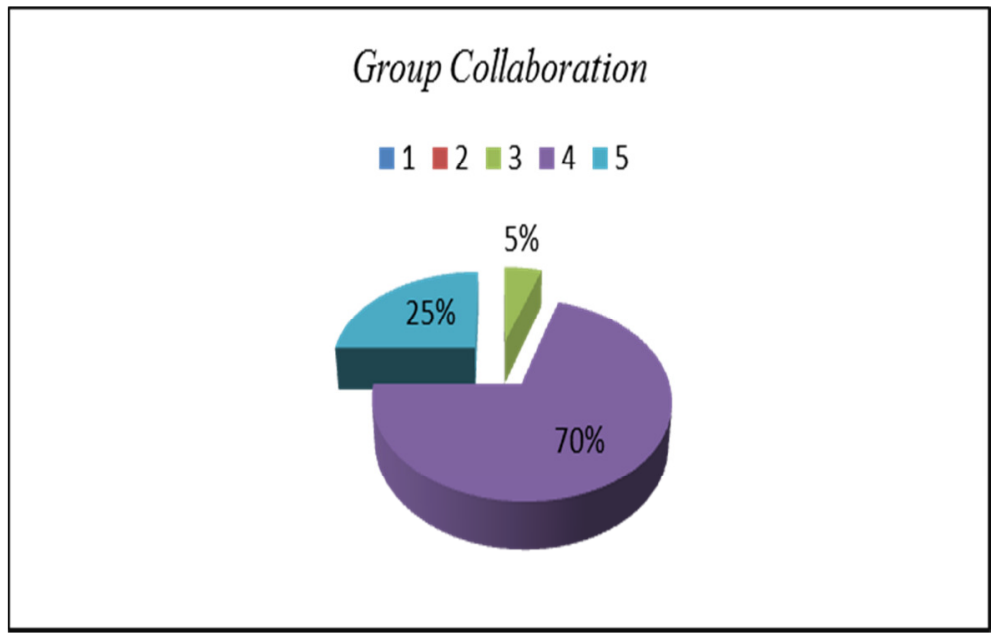

Figure 5. Group collaboration survey.

Figure 5 revealed that $25 \%$ of the students engaged very well, $70 \%$ of the students participated pretty good enough; and 5\% involved themselves fairly satisfactory. This showed the desire or willingness of most students to work effectively in a collaborative environment. Most of the participants stated that through collaborative tasks, they learned how to share information and ideas and be flexible with others views. Upon completion of their research and presentation of their palpable output [i.e. PowerPoint presentation, and 3-D project], each member was asked about his or her experiences or the percentage of his or her contribution to the team. Each member should emphasize what he or she contributed and point out failures of the other team members. It was worthy to note that the teacher was inspired with the level of participation and engagement by all participants. In follow-up interviews, it seems that although there were few students expressed negative feelings toward their group mates, most of them found that they were more motivated to work on their assignment, as such the students were more heedful to the details to be learned.

Teacher: What do you enjoy most about working for your group task?

Student 1: ...everyone would contribute what she or he was good at..

Student 10: ... trying to help one another as much as we could.

Student 8: ... it was fun but a bit frustrating when some didn't care how to do it.

Nonetheless, this observation agreed with Yoder (1999), Watson (1999), Castronova (2002), Mohn (2003), Dudeney (2003), March (2004), and Ikpeze \& Boyd (2007), that WebQuest promotes collaboration among students.

The survey's second question was, "Rate your creativity level in doing your WebQuest project". Figure 6 revealed that $20 \%$ of the students gave themselves very high ratings in creativity level, $65 \%$ of them rated high, $10 \%$ of them rated fairly and $5 \%$ of them showed scarce creativity. It seems that students perceived WebQuest experiences had helped them enhance their creativity level. As apprenticed to real life roles and self-directed 
learners, participants were required to complete a variety of tasks, and as a consequence, the quality of their product or presentation may rely heavily upon their ability to participate in creating and planning. Within this authentic activity, participants were encouraged to collaborate and generate feedback among them. Feedback that was exchanged between participants and with their teacher allowed them to enhance their creativity level. As discussed by Davidson and Stobbeleir (2011), feedback is positively related to creative performance. However, further research in this aspect should address an in-depth analysis of WebQuest impact on creativity.

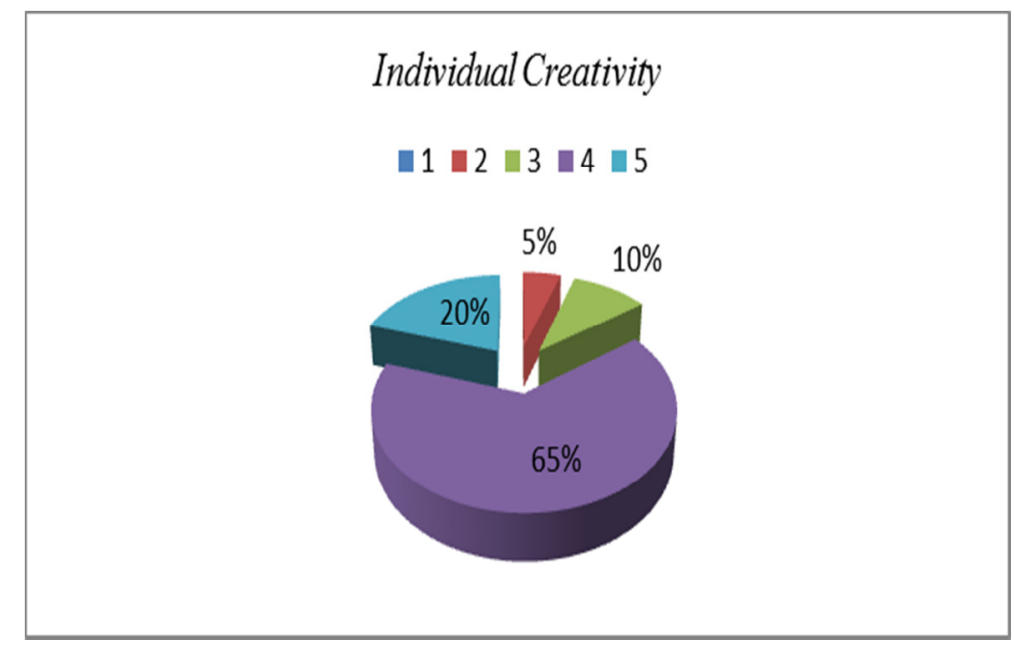

Figure 6. Creativity level survey.

The survey's third and fourth questions had something to do with time management and prioritizing task. The Questions were, "Do you spent enough time researching relevant information?" and "Did you use your budgeted time efficiently?" Figure 7 shows that $25 \%$ of the students rated very high in prioritizing task, $50 \%$ gave themselves a high rating and $25 \%$ of them rated fairly. Furthermore, Figure 8 shows that only $15 \%$ of the students rated very high in time management, $25 \%$ of them rated next to it, $35 \%$ of them rated fairly and $25 \%$ rated themselves quite low in this aspect. This only shows that although most of the students spent enough time in delving into details of their task, they found it very difficult to manage the time for each undertaking and to finish their project. For several instances some students were asked, "Are you satisfied with your output or project?

“...not really. We did the project in a rush. Exactly the day before the submission.."

“...we crammed everything..”

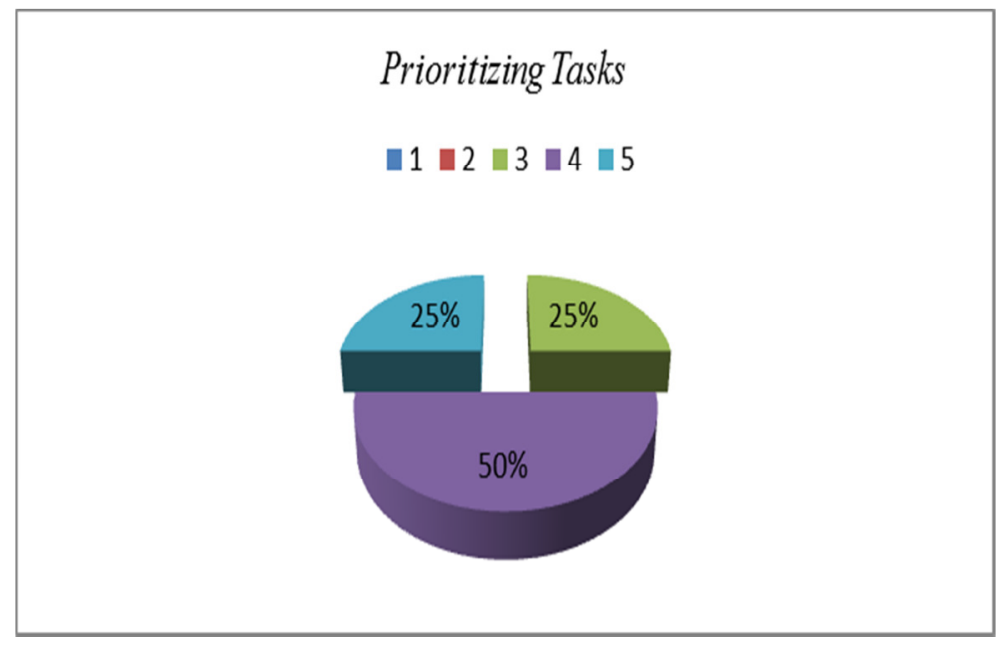

Figure 7. Prioritizing task survey. 
Because of the less -structured nature of WebQuest, there was a good chance that students could get distracted during the course of an activity. And this "feeling" is corroborated by the remarks from a group saying,

“...not really...because sometimes we tend to talk that are not related to the quest."

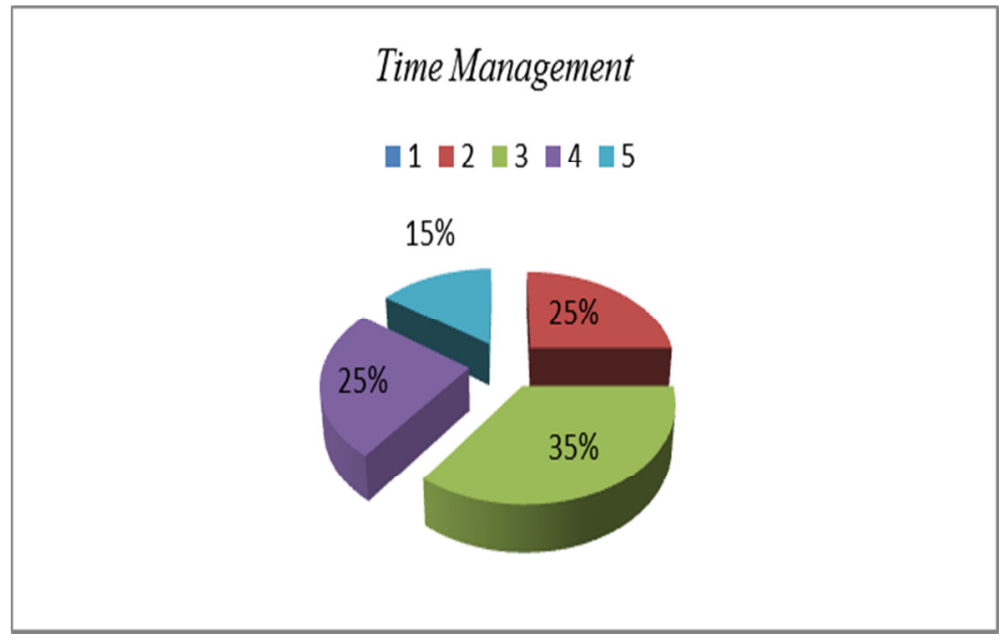

Figure 8. Time management survey.

The researcher felt that aside from the required skills [i.e. computer and reading skills]; time management was also needed, unfortunately, most of the students found to have difficulty in this aspect. More specifically, the time needed to uncover and organize the information acquired from the various Web sites.

The survey's fifth question was, "Did you enjoy completing your WebQuest?" Figure 9 revealed that at the end of the activity, $50 \%$ of the participants rated this aspect as strongly agree, $40 \%$ rated next to it, and $10 \%$ of them rated fairly. Essentially, the students found the WebQuest experience positive. This confirms the observations of the researcher that most of the students were incline toward online activity and were more interested in an 'authentic task'. It seems that for many students, WebQuest was a motivating factor. Some students commented:

\footnotetext{
"Yes, because it's not the boring classroom type."

"Yes, it's fun especially if you learned something new."

“...it was very interesting class..”

“...Yes, I learned a lot because the web quest was really informative and useful. “

“...Yes, because it was easy to understand and entertaining”.
}

However, few students disapproved of having a group activity and then get stuck while doing a group project. This was confirm by a group saying,

"Yes, it's enjoyable once you know what to do".

"...very effective for those who will take it seriously. Like for me the time given each project is not enough although it was a good thing which made me responsible.." 


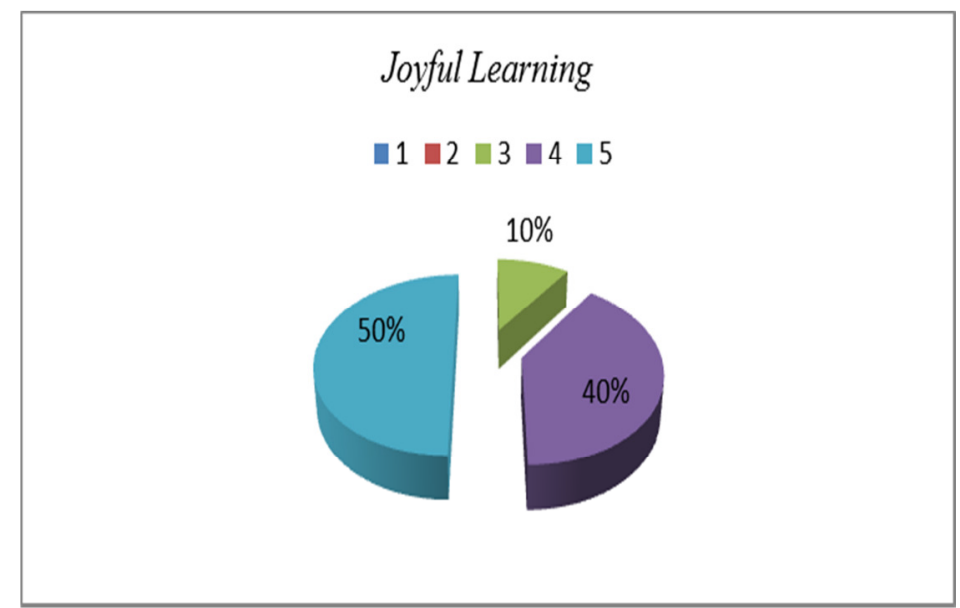

Figure 9. Engagement and enjoyment of learning Physics survey.

Overall, it appeared that the WebQuest activities did promote joyful learning experience that inspired the participants to study harder. The reasons for this, according to March (2004), were as follows: scaffolded learning structure, authentic task, development of individual expertise and participation in a group process. Based on Piaget and Vygotsky's theory, (Eggen \& Kauchak, 2004), both agreed that active learners and social interaction are important for development. Specifically learners within the ZPD [Zone of Proximal Development] can benefit from assistance or collaboration and instructional scaffolding. For example, on new or difficult WebQuest task, before students could proceed to complete their assignment, it involves verbally suggested ideas from all members of the group that would help any one of them identify the desired information. Moreover, on the course of the WebQuest activity, the teacher assisted students consistently and provided the best sources or web sites worth visiting so that students can concentrate on their task rather than wandering. Consequently, WebQuest increased student motivation and made learning enthralling for the students. This observation was also reflected in a study by Mohn (2003), Murray (2006), Tsai (2006), and Gaddy (2007).

The survey's sixth question was, "Do you feel that you learned a lot about the topic that you researched?" Figure 10 shows that $65 \%$ of the students rated the highest in enhancing learning, $25 \%$ of them rated next to it, $5 \%$ of them rated fairly and $25 \%$ of them rated themselves quite low in this aspect. This indicates that students perceived to acquire knowledge by visiting different web sites including the ones previously selected by the teacher. These findings were consistent with earlier studies of Mohn (2003), Murray (2006), Ikpeze \& Boyd (2007), Gaddy (2007), and Gowen (2010) which claimed that students did acquire content knowledge and demonstrated content acquisition through WebQuest model.

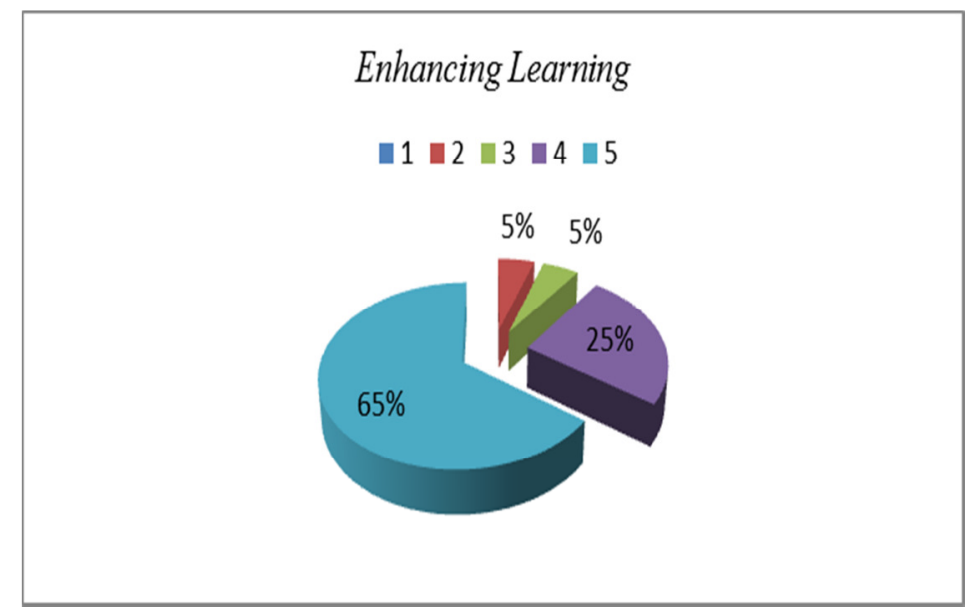

Figure 10. Content-knowledge Acquisition Survey. 
The survey's last question was, "Now that you have completed this WebQuest, what are your thoughts or feelings [reaction] toward this strategy for learning physics? In general, students have a positive perception about the WebQuest and that they think it helped them learn some Physics concepts. Some of the students' felt that:

"Learning through 'WebQuest” is really fun and effective way of learning because as a student, when a subject or topic is approached in a lively and "fun" manner, it will be more memorable and vivid when I reminisce about these basic topics. It's very cool and efficient. Less time is wasted...technology is used efficiently".

"It is much better way than any other way to learn physics. It is much easier and enjoyable way to understand physics. WebQuest taught me a lot and explains me in a better way because a lot of drills and task are given to really know the topic"

"At first time, physics was the worst subject for me but now I appreciated to learn this class ...it's so meaningful and excited..."

"Actually, I seriously had a hard time with Physics. But this quarter I enjoyed learning physics because I knew how to enjoy it...I accepted and had fun. I learned a lot and got inspiration."

“...this makes me realize that Physics isn't that hard after all...”

"I love Physics ...there are just some topics that I don't like..."

Although WebQuest did appear to have considerable advantage [i.e. students were to some extent self-directed and enhanced content knowledge etc.], there was always risk if the links previously chosen by the teacher do not open. Actually, during WebQuest intervention, it was one of the common errors encountered by students. When this glitch occurred, the teacher assisted each group in finding alternative sites for them not to get stuck. Moreover, it was also notable that some students found it difficult to follow the discussions on some topics [e.g. circular motion and Newton's laws of motion]. When the teacher noticed that students did not understand the content or answer the question, he would then focus on the questions and guide them to locate pertinent information about the concept. An opinion expressed by a student was:

"Physics is difficult subject, but I like it. It is fun to learn. I just don't like exam or doing difficult thing what I don't get. ...through WebQuest I learned more easily and having fun.”

In summary, the students' perceptions about WebQuest were largely encouraging. Some conflicting views among students, however, were found. Five of the six survey questions had overall positive ratings. Hence, students viewed WebQuest favourably irrespective of their ability to learn and it suggests that WebQuest model can be a useful tool for student learning. The results of this study corroborated the earlier observations of Mohn (2003), Santavenere (2003), Leite, McNulty, \& Brooks (2005), Murray (2006), Tsai (2006), Gaddy (2007), Ikpeze \& Boyd (2007), Gowen (2010), and Cheng, Tzung, \& Wei (2011).

\section{Conclusion}

This study addressed five research questions and showed the following findings:

1. Exposure to the WebQuest model improved students' critical thinking, specifically, on their deductive reasoning

2. Exposure to WebQuest model, enhanced students' deductive reasoning. On the contrary, it does not boosted assumptions identification.

3. Exposure to the WebQuest model promoted students' performance in content-knowledge acquisition. 
The WebQuest: Its impact on students' critical thinking, performance, and perceptions in physics

4. The students' performance of the learning task had significant correlation with their critical thinking skills, specifically on deduction aspect.

5. Students viewed WebQuest favourably irrespective of their ability to learn and this suggests that WebQuest model can be a useful tool for learning basic Physics.

\subsection{Recommendations}

Although it is worth noting that the findings of this study indicate significant benefits from the WebQuest model, carefully conducted research should be done at different grade levels and in a variety of disciplines. Specifically, future research might include a study which the sample is large enough and is conducted over a much longer period of time in between the pretest and posttest.

\section{Acknowledgment}

The authors wish to thank to all members of MITIS community who cared enough and freely gave their time to participate. This research was generously supported by the DOST-SEI. Thank you.

\section{References}

Abbit, J., \& Ophus, J. (2008). What we know about the impacts of WebQuests: A review of research. AACE Journal, 16(4), 441-456.

Alice, A. (2007, July 7). Dr. Alice Christie's WebQuest article. Dr. Alice Christie's Site. Retrieved June 15, 2008, from http://alicechristie.org/edtech/wq/about.html

Brown, K. (1998). Education, culture, and critical thinking. Aldershot, England: Ashgate.

Castronova, J. (2002). Discovery learning for the 21st century: What is it and how does it compare to traditional learning in effectiveness in the 21st century? Action Research Exchange, 1(1). Retrieved June 11, 2009, from http://chiron.valdosta.edu/are/

Cheng, S. C., Tzung, S. C., \& Wei, H. H. (2011). The study on integrating WebQuest with mobile learning for environmental education. Computers \& Education, 57(1), 1228-1239.

Chou, T. (2007). The effect of the WebQuest writing instruction on EFL learners' writing performance, writing apprehension, and perception. TESL-EJ, 11(3). Retrieved December 5, 2010, from http://www.tesl-ej.org/ej43/a3.pdf

Crawford, C., \& Brown, E. (2002). Focus upon higher order thinking skills: Webquests and the learner-centered mathematical learning environment. Retrieved June 10, 2009, from www.eric.ed.gov/ERICWebPortal/recordDetail?accno=ED474086

Davidson, T., \& Stobbeleir, K. D. (2011, September 7). The power of the feedback environment in stimulating creative performance: the role of task autonomy and self-concordance. EconPapers. Retrieved September 15, 2011, from http://econpapers.repec.org/paper/vlgvlgwps/2011-09.htm

Dewey, J. (1998). How we think: a restatement of the relation of reflective thinking to the educative process. Boston: Houghton Mifflin.

Dodge, B. (1997, May 5). Some thoughts about WebQuests. Webquest.Org. Retrieved February 15, 2008, from http://webquest.sdsu.edu/about_webquests.html

Dodge, B. (2002, May 17). A taxonomy of WebQuest tasks. WebQuest. Retrieved February 15, 2008, from http://webquest.sdsu.edu/taskonomy.html

Dodge, B. (2007, August 9). What is a WebQuest?. WebQuest.Org: Home. Retrieved February 15, 2008, from http://webquest.org/index.php

Dudeney, G. (2003). The quest for practical web usage. TESL-EJ, 6(4). Retrieved February 16, 2008, from http://tesl- ej.org/ej24/int.html

Eggen, P. D., \& Kauchak, D. P. (2004). Educational psychology: Windows on classrooms. Upper Saddle River, N.J.: Pearson/Merrill Prentice Hall. 
Auditor, E., \& Roleda, L.

Ennis, R. H., Millman, J., \& Tomko, T. (2005). The Cornell CT Test Levels X and Z Manual (5th ed.). Pacific Grove, CA: Midwest Publications.

Gaddy, Janet S. (2007). The influence of technology-based instruction on student learning, motivation and teacher perceptions toward science instruction. Unpublished Masteral thesis. Georgia: Valdosta State University.

Gowen, Deborah C. (2010). The relationship of motivation and multiple intelligence preference to achievement from instruction using Webquests. Unpublished Doctoral dissertation. Minneapolis: WaldenUniversity.

Herr, N. (2007, January 1). Activities for inductive reasoning. The Sourcebook for Teaching Science. Retrieved July 29, 2008, from http://www.csun.edu/science/ref/reasoning/inductive_reasoning/inductive_reasoning.html

Ikpeze, C., \& Boyd, F. (2007). Web-based inquiry learning: Facilitating thoughtful literacy with WebQuests. The Reading Teacher, 60(7), 644-654.

Jarus, J. T. (2001). Construct-related validity of the Toglia Category Assessment and the deductive reasoning test with children who are typically developing. Retrieved June 15, 2009, from http://www.ncbi.nlm.nih.gov/pubmed/14601812

Leite, M., McNulty, A., \& Brooks, D. (2005). "Learning from WebQuests”. Paper presented at National Educational Computing Conference 2005. Retrieved July 15, 2008, from http://ebookbrowse.com/20060320-\%E4\%BE\%AF\%E6\%98\%8E\%E8\%B3\%A2-learning-from-webque st-doc-d126275073

Lombard, B., \& Grosser, M. (2004). Critical thinking abilities among prospective educators: Ideals versus realities. South African Journal of Education, 24(3), 212-216.

Mohn, N. (2004). The effectiveness of the WebQuest model with gifted fifth grade students. Action Research Exchange, 3(1). Retrieved July 10, 2008, from http://teach.valdosta.edu/are/vol3no1/pdf/MohnNL_article.pdf

Murray, R. (2006). WebQuests celebrate 10 years: Have they delivered? Action Research Exchange, 5(1). Retrieved November 10, 2009, from http://teach.valdosta.edu/are/vol5no1/Thesis\%20PDF/MurryR_ARE.pdf

Puthikanon, N. (2009). Examining critical thinking and language use through the use of WebQuests in an EFL reading class. Unpublished Doctoral dissertation. Indiana Univesity. Retrieved August 11, 2010, from Proquest database.

Rodriguez, S. (2003). Designing WebQuests to promote problem-solving skills (Abstract). In C. Crawford et al. (Eds.), Proceedings of Society for Information Technology \& Teacher Education International Conference 2003 (pp. 2164-2167). Chesapeake, VA: AACE. Retrieved June 05, 2008, from http://editlib.org/p/18378

Santavenere, A. (2003). The effects of educational technology upon the critical thinking and analytical skills of below grade-level and or non-college bound high school students. Unpublished Masteral thesis, Salisbury University, Maryland.

Scardamalia, M., \& Bereiter, C. (1999). Schools as knowledge building organizations. In D. Keating \& C. Hertzman (Eds.), Today's children, tomorrow's society: The developmental health and wealth of nations (pp. 274-289). New York: Guilford. Retrieved June 05, 2008, from http://www.ikit.org/fulltext/1999schoolsaskb.pdf

Tsai, S. H. (2006). Integrating WebQuest learning into EFL instruction. Retrieved June 05, 2009, from http://www.editlib.org/noaccess/22369

Vanguri, P., Szymanski, C., Wilson, E., \& Wright, V. (2004). WebQuests in social studies education. Journal of Interactive Online Learning, 3(2). Retrieved June 6, 2008, from http://www.ncolr.org/jiol/issues/pdf/3.2.5.pdf

Vidoni, K., \& Maddux, C. (2002). WebQuests: can they be used to improve critical thinking skills in students? The ACM Digital Library, 19, 101-117.

Watson, K. L. (1999). WebQuests in the middle school. Meridian, 2(2). Retrieved June 6, 2008, from http://www.ncsu.edu/meridian/jul99/webquest/webquest2.html 
The WebQuest: Its impact on students' critical thinking, performance, and perceptions in physics

Wiggins, G. (1990). The case for authentic assessment. Practical assessment, research \& evaluation, 2(2). Retrieved June 15, 2008, from http://pareonline.net/getvn.asp?v=2\&n=2

Yoder, M. B. (1999). The student WebQuest: A productive and thought-provoking use of the internet. Learning and leading with Technology, 26(7). Retrieved July 5, 2008, from http://www.jcu.edu/education/dshutkin/ed186/studentwebquest.pdf 
Auditor, E., \& Roleda, L. 